\title{
Therapeutic efficacy of Brucella phage against Brucella abortus in mice model
}

\author{
A. Prajapati, D. Ramchandran, H. Verma, M. Abbas and M. Rawat
}

Division of Biological Standardization,

Indian Veterinary Research Institute (IVRI), Izatnagar - 243122, Dist. Bareilly, Uttar Pradesh, India

Corresponding author: Awadhesh Prajapati, email: avi75prajapati@gmail.com

Received: 27-10-2013, Revised: 05-12-2013, Accepted: 14-12-2013, Published online: 27-01-2014

doi: $10.14202 /$ vetworld.2014.34-37

How to cite this article: Prajapati A, Ramchandran D, Verma H, Abbas M and Rawat M (2014) Therapeutic efficacy of Brucella phage against Brucella abortus in mice model, Veterinary World 7(1): 34-37.

\begin{abstract}
Aim: To investigate the preventive and therapeutic potential of brucella phage in experimentally infected mice with Brucella abortus (strain 544).

Materials and Methods: Three groups of mice each containing 6 individuals were infected with Brucella abortus (strain 544). A preventive group was infected with Brucella abortus (strain 544), $48 \mathrm{hrs}$ before phage treatment. A therapeutic group was phage treated $48 \mathrm{hrs}$ after Brucella abortus (strain 544) infection in mice. Spleen was aseptically collected from all groups of mice 15 days after challenge. Mean Spleen count of Brucella was enumerated by culturing on Brucella agar media (BAM) and converted in terms of protective activity and compared with control mice not receiving phage therapy.

Result: There was significant reduction in protective activity of preventive and therapeutic phage treated groups (2.884 and 3.077) respectively in comparison to control group mice (4.267). There was no significant effect on mice health following phage treatment.
\end{abstract}

Conclusion: phage treatment is a promising alternative for reducing Brucella colonization in mice.

Keywords: brucella phage, spleen count, phage therapy.

\section{I ntroduction}

Brucellosis is an important re-emerging zoonotic infectious disease $[1,2]$. It is characterized by abortions, stillbirths and reproductive problems in ruminant [3]. Human beings get infected accidently by contact with vaginal discharges, fetal fluids [3] or by ingestion of unpasteurized milk [4]. Five out of nine species of Brucella can infect humans in which most pathogenic for human is $B$. melitensis and followed in descending order by B. suis, B. abortus, B. canis and recently isolated marine Brucellae (B. ceti) [5].

Bovine brucellosis is widespread in India and has been reported from almost all states $[1,6]$. An appropriate antibiotic therapy for animals and human beings is still disputed [7-9] and it is too expensive in most of the animal species. so use of lytic phage to treat brucellosis can be another alternative to this important disease

Phages are viruses that infect and multiply inside the bacteria and can have two types of life cycles, lytic and lysogenic [10]. The lytic phages are the most suitable for phage therapy as they quickly reproduce within and lyse the bacteria and grow exponentially in the number [11]. Bacteriophages are virus that use specific bacterial species as host, and reduce the number of viable bacterial cells without significant affecting commensal gut flora often caused by broad-

Copyright: The authors. This article is an open access article licensed under the terms of the Creative Commons Attribution License (http://creativecommons.org/licenses/by/2.0) which permits unrestricted use, distribution and reproduction in any medium, provided the work is properly cited. spectrum antibiotics [12]. Phage replicates as long as the targeted host bacterium is present and thus they are naturally self-limiting [13]. Recently, phage therapy has regained general interest as resistance to antibiotics has become a serious problem $[14,15]$ and is found to be effective to treat many bacterial infections [16-18].

The use of host-specific bacteriophages has been promoted as a cost-effective and adaptable approach to control zoonotic bacteria like Brucella and Salmonella [19] and have potential to be developed as effective agents to prevent and treat animal bacterial diseases $[20,21]$. The objective of this study was to investigate the efficacy of phage treatment in reducing Brucella colonization and infection in mice.

\section{Materials and Methods}

Animals: Apparently healthy female Swiss albino mice $(n=26)$ (4 to 6 weeks age) were obtained from the Laboratory Animal Resource section, Indian Veterinary Research Institute (IVRI), Izatnager. The animals were kept under conventional housing condition and provided feed and water ad labium.

Ethical approval: The animal ethics committee of Indian Veterinary Research Institute, deemed university approved the study.

Bacterial cultures: B. abortus 19, B. abortus 544, B. melitensis 16M, B. melitensis Rev 1, B. suis 1303 were obtained from the Brucella Referral Laboratory, Division of Veterinary Public Health, IVRI, Izatnagar. Salmonella, Staphylococcus, E. coli and Pasturella 
used from Type Culture Lab, Division of Biological Standardization IVRI.

Phage lytic to Brucella spp: Phage lytic to $B$. abortus (strain 19) obtained from Department of Veterinary Microbiology, Veterinary College, Guru Angad Dev Veterinary and Animal Science University (GADVASU), Ludhiana, Punjab, India [22].

Preparation of phage stock: Working stock of isolated phage was prepared by seeding $500 \mathrm{ml}$ flask containing $100 \mathrm{ml}$ of NZCYM medium (Sodium chloride,Casein enzymic hydrolysate, Casein acid hydrolysate, Yeast extract, Magnesium sulphate, heptahydrate) (Himedia, Mumbai) with $0.5 \mathrm{ml}$ suspension of $B$. abortus 19 harvested from $48 \mathrm{hrs}$ grown culture on Brucella agar medium (Difco, USA) slant into sterile PBS (pH 6.8). Phage suspension added in this culture after $12 \mathrm{hrs}$ (log phase) and incubation for $48 \mathrm{hrs}$ at $37^{\circ} \mathrm{C}$. Culture were centrifuged at $10000 \mathrm{~g}$ for $10 \mathrm{~min}$. Supernatant fluid was then sterilized by passage through a membrane filter $(0.22 \mu$, Millipore filter crop, U.S.A $)$ and kept at $4^{\circ} \mathrm{C}$. Titer $(\mathrm{pfu} / \mathrm{ml})$ of these phage stock determined by double overlay technique [23].

Test for toxicity of phage preparation: In separate experiments, the tested phage was administered i.p. (Intra peritoneal) to mice to determine the toxicity of phage in vivo. Three concentrations of the phage preparation $\left(10^{6} \mathrm{PFU} / \mathrm{ml}, 10^{7} \mathrm{PFU} / \mathrm{ml}\right.$, and $\left.10^{8} \mathrm{PFU} / \mathrm{ml}\right)$ were tested on mice. Two mice were injected with 0.5 $\mathrm{ml}$ of each phage preparations along with 2 mice received $0.5 \mathrm{ml}$ sterile PBS. A 7 day observation was made to see any toxic effect of phage preparation in terms of mortality and reduced weight gain.

Host range determination: The phage were tested for their ability to lyse different strains of B. abortus also with other species of the genus Brucella, Salmonella, Staphylococcus, Pasturella and E.coli. Bacteriophage lysis assay was based on the modified method of the traditional double-layer plaque technique [24]. The top agar layer consisted of NZCYM broth containing $0.75 \%$ agar. For each bacterial strain tested, $3 \mathrm{ml}$ of top semisolid agar was melted for $10 \mathrm{~min}$ and allowed to cool to $47^{\circ} \mathrm{C}$. After adding $100 \mu \mathrm{l}$ of overnight culture of bacterium to be tested on the melted agar, the melted mixture was vortexed and poured on a Brucella agar media plate. The top agar was allowed to solidify at room temperature and $30 \mu \mathrm{l}$ phage suspensions $\left(10^{8}\right.$ $\mathrm{PFU} / \mathrm{ml}$ ) were spotted onto the top layer. The plate was incubated at $37^{\circ} \mathrm{C}$ for $48 \mathrm{hrs}$ and then examined for the presence of zone of lysis. (B. abortus 544 placed in $5 \%$ $\mathrm{Co}_{2}$ ).

Examination of phage (Electron Microscopy): Phagecontaining solutions $\left(10^{8} \mathrm{pfu} / \mathrm{ml}\right)$ were mixed with $1 / 10$ volume of $2.5 \%$ buffered glutaraldehyde for $5 \mathrm{~min} .25$ $\mu l$ of fixed phage were added to the surface of a piloform coated grid and left for $2 \mathrm{~min}$. After removing excess fluid grid was washed for 2 seconds in distilled water. Negative staining of phage was performed by adding 1 drop of $2 \%$ phasphotungstic acid (PTA) to the grid surface. After drying for $20 \mathrm{~min}$ in the air grids were observed with a JEOL transmission electron microscope [25].

Phage therapy trials: Three groups of six-week-old female Swiss albino mice each containing 6 individual were infected with $2 \times 10^{5} \mathrm{CFU} \quad B$. abortus 544 in 0.1 $\mathrm{ml}$ PBS (pH 7.2) i.p. CFU determined as the method described by [26]. Preventive and therapeutic groups were treated with $10^{6} \mathrm{cfu} / \mathrm{ml}$ of phage in $0.1 \mathrm{ml}$ of PBS (7.2) i.p., $48 \mathrm{hrs}$ before and $48 \mathrm{hrs}$ after infection respectively [27]. Control groups of mice were inoculated with $0.1 \mathrm{ml}$ PBS (7.2), i.p.

Splenic growth of challenge strain in Swiss Albino mice: All mouse were killed by cervical dislocation 15 days post-infection and spleens were removed aseptically, homogenized individually in 9 time to weight of spleen in buffered saline solution (BSS: $\mathrm{NaCl}$ $8.5 \mathrm{~g}$; $\mathrm{KH}_{2} \mathrm{PO} 41.0 \mathrm{~g}$; $\mathrm{K}_{2} \mathrm{HPO} 42.0 \mathrm{~g}$; distilled water $1000 \mathrm{ml} ; \mathrm{pH} 6.8)$ and three tenfold dilutions were done $(1 / 10,1 / 100$ and $1 / 1000)$ in the BSS and $0.2 \mathrm{ml}$ of each dilution was seeded in BAM (brucella agar media) plates (Difco, USA) (4 plate for each dilution, $2 \mathrm{kept}$ aerobically and $2 \mathrm{kept}$ in $5 \% \mathrm{CO}_{2}$ ). Plates were incubated at $37^{\circ} \mathrm{C}$ for 4 to 5 days to determine the CFU/spleen; Colonies of Brucella should be enumerated on the dilutions corresponding to plates showing fewer than $300 \mathrm{CFU}$. When no colony was seen in the plates corresponding to the 1/10 dilution, the spleen was considered to be infected with five bacteria. These numbers of Brucella per spleen are first recorded as $\mathrm{X}$ and expressed as $\mathrm{Y}$, after the following transformation: $\mathrm{Y}=\log (\mathrm{X} / \log \mathrm{X})[28,29]$.

Statistical analysis: Data obtained in the study were analysed statistically on 'SPSS-16.0' software package as per standard methods [30]. Data were subjected to one way analysis of variance and level of significance among the treatments.

\section{Results and Discussion}

Phage was found lytic to culture of B. abortus 99 , B. abortus 19, B. abortus 544, B. melitensis Rev1, and B. suis 1330 , but not to Salmonella abortus equi E742 and E789, Salmonella pullorum, Pasturella multocida $\mathrm{P}_{52}$ and Staphylococcus aureus and E. coli. This finding is in accordance with findings of Chachra [21]. This observation showed that the phage was specific to Brucella genus and not to other gram +ve or gram -ve bacteria tested in the lab which give advantage that it might be not affect other bacteria flora in the body. Electron microscopy of the phage showed somewhat rounded head with a short tail, consistent with the previously report that most of brucella phage have short tails $[31,32]$. A titer of phage used in therapy was $10^{6} \mathrm{PFU} / \mathrm{ml}$. It comes into medium range of concentration that was suitable for phage therapy [33]. 
Table-1. Protective activity of phage in preventive group mice

\begin{tabular}{|c|c|c|c|c|c|c|}
\hline \multirow[t]{2}{*}{ Mice No. } & \multicolumn{3}{|c|}{ Average total spleen colony count (X) } & \multicolumn{2}{|c|}{ Protective activity } & \multirow[t]{2}{*}{ Average Protective activity (Y) } \\
\hline & $1: 10$ & $1: 100$ & $1: 1000$ & $1: 100$ & $1: 1000$ & \\
\hline 1 & $U$ & 3500 & 2000 & 2.994 & 2.782 & 2.888 \\
\hline 2 & U & 2000 & 1000 & 2.782 & 2.522 & 2.652 \\
\hline 3 & U & 1200 & 3000 & 2.590 & 2.935 & 2.763 \\
\hline 4 & U & 8000 & 7000 & 3.311 & 3.260 & 3.285 \\
\hline 5 & U & 4400 & 4000 & 3.081 & 3.045 & 3.063 \\
\hline 6 & U & 2000 & 1000 & 2.782 & 2.522 & 2.652 \\
\hline
\end{tabular}

$\mathrm{U}=$ uncountable, $\mathrm{Y}=\log (\mathrm{X} / \log \mathrm{X})$ where $\mathrm{X}=$ total $\mathrm{CFU} /$ spleen

Table-2. Protective activity of phage in therapeutic group mice.

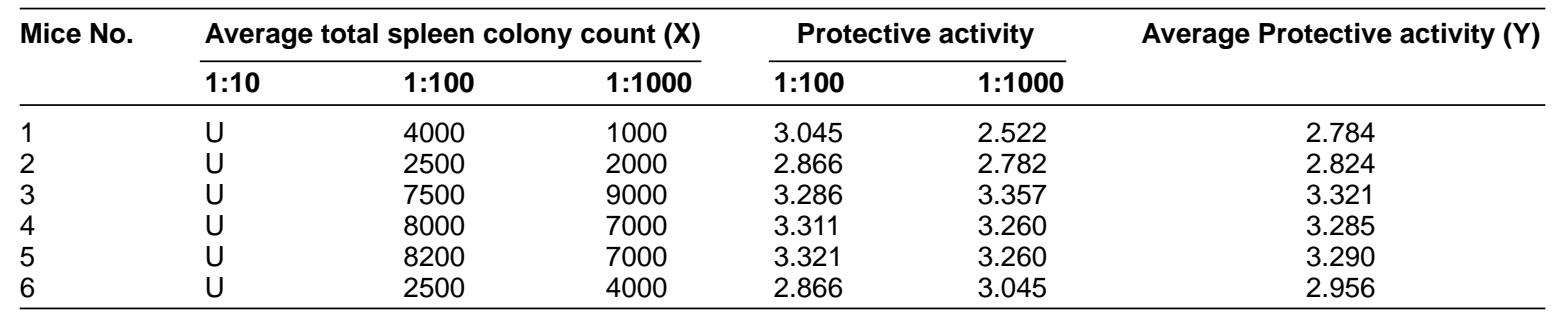

$\mathrm{U}=$ uncountable, $\mathrm{Y}=\log (\mathrm{X} / \log \mathrm{X})$ where $\mathrm{X}=$ total $\mathrm{CFU} /$ spleen

Table-3. Protective activity of PBS in control group mice.

\begin{tabular}{lllll}
\hline Mice No. & \multicolumn{2}{l}{ Average total spleen colony count (X) } & Protective activity \\
\cline { 2 - 5 } & $\mathbf{1 : 1 0}$ & $\mathbf{1 : 1 0 0}$ & $\mathbf{1 : 1 0 0 0}$ & \\
\hline 1 & $\mathrm{U}$ & $\mathrm{U}$ & 80000 & 4.212 \\
2 & $\mathrm{U}$ & $\mathrm{U}$ & 120000 & 4.373 \\
3 & $\mathrm{U}$ & $\mathrm{U}$ & 60000 & 4.098 \\
4 & $\mathrm{U}$ & $\mathrm{U}$ & 75000 & 4.187 \\
5 & $\mathrm{U}$ & $\mathrm{U}$ & 20000 & 4.098 \\
6 & $\mathrm{U}$ & 230000 & 4.632 \\
\hline
\end{tabular}

Table-4. Camparision of mean protective activity of three group

\begin{tabular}{lc}
\hline Group & Mean Protective activity \pm SE \\
\hline Preventive & $2.884 \pm 0.103^{\mathrm{a}}$ \\
Therapeutic & $3.077 \pm 0.102^{\mathrm{a}}$ \\
Control & $4.267 \pm 0.084^{\mathrm{b}}$ \\
\hline
\end{tabular}

Means within each column bearing common superscript do not differ significantly $(P<0.05)$

$\mathrm{SE}=$ standard error
$\mathrm{U}=$ uncountable, $\mathrm{Y}=\log (\mathrm{X} / \log \mathrm{X})$ where $\mathrm{X}=$ total $\mathrm{CFU} /$ spleen

Toxicity study of the phage preparation in mice showed that it was nontoxic to mice as there was no mortality and untoward reaction seen in the 7 day observation period after administration.

Spleen count of B. abortus 554 did 15 days after administration of phage [28, 29]. It was found that the mean protective activity of phage was $2.88,3.08$ and 4.27 in protective, therapeutic and control group's mice respectively (Table-1, 2, 3 and 4). Protective activity was significantly $(\mathrm{P}<0.05)$ decrease in the preventive and therapeutic group as compared to control group (Table-4). It means that there is significantly reduced in spleen count of both phage treated group as compare to the non treated control group. This observation was supported by the work of Parnas; Pamas and Burdzy [34-36] who established that brucella phage possesses certain preventive properties against experimental challenge. The reduction in colony count of Brucella was found to be higher in the $1^{\text {st }}$ group, in accordance with the finding of Drozevkina; Pophadze $[37,38]$ who demonstrated that the introduction of the phage into the organism at the same time or immediately after infection lead to the localization of the causative agent and increase the sterilization of the organism. Reduction in the spleen count of Brucella with of a single dose of phage after 15 DPI suggest that the phage could be stable and active in vivo for a longer duration This finding is also supported by the work of Pophadze [39] who showed that brucella phage is capable of persisting for a long time both in a healthy guinea pig (up to 30 days) and in a guinea pig infected with brucellosis (over 45 days). Recently many trails of phage therapy in mice, poultry and cattle showed that phages are effective promising alternatives to bacterial infection [40,41].

\section{Conclusion}

It is clear from this study that application of phage is an effective mean to reduce the colonization of Brucella in the spleen of mice. Since the use of antibiotic in brucellosis in animals was uneconomical and not recommended, the use of the phage to treat the animal especially pregnant animal may help in reducing the chance of threatened abortion and potential transmission to other susceptible animal. This is the preliminary work in this field, and further study is required to find a more appropriate route, dosage and time interval to get maximum result and more experiments are needed to make this therapy applicable to all conditions of brucellosis.

\section{Authors' contributions}

MR designed the study and all the other author performed research experiment. AP and HV carried out the statistical analysis. MR drafted and revised the manuscript. All authors read and approved the final manuscript.

\section{Acknowledgements}

The authors are thankful to Deepti Chachra and H. M. Saxena, Department of Veterinary Microbiology, 
Veterinary College, GADVASU, Ludhiana, Punjab, India for providing brucella phage and Director, IVRI Izatnagar for providing sufficient fund and laboratory facilities to conduct this research.

\section{Competing interests}

The authors declare that they have no competing interests.

\section{References}

1. Mantur, B.G. and Amarnath, S.K. (2008) Brucellosis in India-a review; J. Biosci., 33: 539-547.

2. Manish, K., Puran, C., Rajesh, C., Teena, R. and Sunil, K. (2013) Brucellosis: An updated review of the disease. Indian J Ani Sci., 83 (1):3-16.

3. Garin-Bastuji, B and Blasco, J.M. (2008) Caprine and ovine brucellosis (excluding Brucella Ovis), 974-983. In Manual of Standards for diagnostic testes and vaccines. 2008. Office International des Epizooties, Paris, France.

4. Pappas, G., Nikolaos, A., Mile, B. and Epameinondas, T. (2005) NEngl JMed., 352: 2325-2336.

5. Ullah, R.W., Shirazi, J.H., Abubakar, M., Zahur, A.B., Latif, A. and Alam, T. (2013) Genetic diversity, zoonotic risk and "One Health" initiative of bovine brucellosis. Res. J. Vet. Pract., 1(1):5-9.

6. Renukaradhya, G.J., Isloor, S. and Rajasekhar, M. (2002) Epidemiology, zoonotic aspects, vaccination and control/eradication of brucellosis in India; Vet. Microbiol., 90: 183-195.

7. Hall, W.H. (1990) Modern chemotherapy for brucellosis in humans; Rev. Infect. Dis. 12 1060-1099.

8. World Health Organization (2006) Brucellosis in humans and animals. ISBN 9241547138.

9. Del, P., Solera, J. (2012) Systemic review and meta-analysis of randomized clinical trials in the treatment of human brucellosis. PLOS ONE 7: 32090.

10. Harper, D.R., Monk, A.B., Rees, C.D. and Barrow, P. and Hagens, S. (2010) Bacteriophage applications: where are we now? Appl Microbiol., 51: 363-369.

11. Abedon, S.T. and Loc-Carrillo, C. (2011) Pros and cons of phage therapy. Bacteriophage., 1: 111-114.

12. Connerton, P.L. and Connerton. I.F. (2005) Microbial treatments to reduce pathogens in poultry meat, 414-427. In G. Mead (ed.), Food safety control in the poultry industry. Woodhead Publishing Ltd., Cambridge.

13. Cars, O., Högberg, L.D. and Murray, M. (2008) Meeting the challenge of antibiotic resistance. Br. Med. J., 337: 726-728.

14. Hyman, P. and Abedon, S.T. (2010) Bacteriophage host range and bacterial resistance. Adv Appl Microbiol., 70: $217-248$.

15. Kumari, S., Harjai, K. and Chhibber, S. (2010) Topical treatment of Klebsiella pneumoniaeB5055 induced burn wound infection in mice using natural products. J Infect Dev Ctries., 4: 367-377.

16. Wright, A., Hawkins. C.H., Anggard, E.E. and Harper, D.R. (2009) A controlled clinical trial of a therapeutic bacteriophage preparation in chronic otitis due to antibioticresistant Pseudomonas aeruginosa; a preliminary report of efficacy. Clin Otolaryngol., 34:349-357.

17. Hawkins, C., Harper, D., Burch, D., and Anggard, E. (2010) Topical treatment of Pseudomonas aeruginosa otitis of dogs with a bacteriophage mixture: a before/after clinical trial. Vet Microbiol., 146: 309-313.

18. Sulakvelidze, A. and Barrow., P. (2005) Phage therapy in animals and agribusiness, 335-380. In E. Kutter and A. Sulakvelidze (ed.), Bacteriophages: biology and applications. CRC Press, Inc., Boca Raton, FL.

19. Huff, W.E., Huff, G.R., Rath, N.C., Balog, J.M. and Donoghue, A.M. (2003a) Evaluation of aerosol spray and intramuscular injection of bacteriophage to treat an
Escherichia coli respiratory infection. Poult. Sci., 82:11081112.

20. Huff, W.E., Huff, G.R., Rath, N.C., Balog, J.M. and Donoghue, A.M. (2003b) Bacteriophage treatment of a severe Escherichia coli respiratory infection in broiler chickens. Avian Dis., 47:1399-1405.

21. Chachra, D. (2011) Isolation and morphological characterization of a brucellaphage against Brucella abortus strain S19. World congress of biotechnology, Hyderabad India. doi:10.4172/2155-9538.10000S2

22. Adams, M.H. (1959) Bacteriophages. Interscience, Publishers, Inc., New York.

23. Chilamban, C., Rawat, M. and Somvanshi, R. (2004) Preclinical studies on therapy of Staphylococcus aureus mastitis by bacteriophage in mice model. 2004. Indian J Comp. Microbiol. Immunol. Infect. dis., 25: 98-103.

24. Gill, J.J., Svircev, A.M., Smith, R. and Castle, A.J. (2003) Bacteriophages of Erwinia amylovora. Appl Environ Microbiol., 69: 2133-2138.

25. Verma, H., Pramod, D., Abbas, M., Prajapati, A., Ramchandra, D. and Rawat, M. (2013) Isolation and partial characterization of lytic phage against Salmonella Abortusequi, Vet World., 6(2): 72-75.

26. Miles, A. A. and. Misra., S. S (1938) The estimation of the bactericidal power of the blood. J. Hyg., 38: 732-749.

27. María J.G., José M.B., Jean P.G., Ignacio M. and Edgardo M. (2002) What have we learned from brucellosis in the mouse model? Veterinary Research., 43:29. doi:10.1186/12979716-43-29.

28. Bosseray, N. (1993) Control methods and thresholds of acceptability for anti-Brucella vaccines. Dev. Biol. Stand., 79: $121-128$.

29. OIE: Bovine brucellosis. (2011) In Manual of Diagnostic Tests and Vaccines for Terrestrial Animals. World Organization for Animal Health, Paris, France., 1-35.

30. Snedecor, G.W. and Cochran, W.G. (1994) Statistical methods. $8^{\text {th }}$ University Press Ames, Iowa, USA.

31. Chachra, D., Kaur, H., Chandra, M. and Saxena, H. (2012) Isolation, Electron Microscopy And Physicochemical Characterization Of A Brucella phage Against Brucella abortus Vaccine Strain S19. The Internet Journal of Microbiology., 10 (2); 79: 121-128.

32. Ostrovskaja, N.N. and Solov'ev, N.N. (1960) B. Mikrobiol. (Mosk.), No. 11, p. 4.

33. Ryan, E.M., Gorman, S.P., Donnelly, R.F., R.F and Gilmore, B.F. (2011) Recent advances in bacteriophage therapy: how delivery routes, formulation, concentration and timing influence the success of phage therapy. J. Pharm. Pharmacol., 63 (10): 1253-1264.

34. Parnas, J. (1960) Arch. Inst. Pasteur Tunis, 37: 215.

35. Pamas, J. and Burdzy, K. (1961a) Z. Immun. -Forsch., 121: 125.

36. Parnas, J. and Burdzy, K. (1961b) Z. Immun. -Forsch., 122: 453.

37. Drozevkina, M.S., Prostetova, N.P., and Haritonova, T.I. (1959) Trudy Rostovskogo Protivocumnogo Instituta., 14: 173.

38. Pophadze, M.S., Abagidze, T.G. and Karicasvili, L.N. (1959) Study of the clearing effect of Brucellaphage in cases of latent microbial infection., Second Scientific Conference on Bacteriophagy, Tbilisi., 18-21:81.

39. Prostetova, N. P. (1959) Trudy Rostovskogo Protivoc' umnogo Instituta., 16: 117.

40. Oliveira A., Serenoa, R. and Azeredo, J. (2009) The in? uence of the mode of administration in the dissemination of three coliphages in chickens. J Poult Sci., 88: 728-733.

41. Stanford, K., McAllister, T.A., Niu, Y.D. (2010) Oral delivery systems for encapsulated bacteriophages targeted at Escherichia coli O157:H7 in feedlot cattle. J Food Prot., 73: 1304-1312. 